\title{
Using Lichenometry, Dendrochronology, and Historical Data to Establish the Relative Age of an Abandoned Cemetery in Northern Arkansas
}

\author{
Brandy Garrett Kluthe ${ }^{1 *}$, Margaret Guiccioni ${ }^{2}$, and Steven L. Stephenson ${ }^{3}$ \\ ${ }^{1}$ Department of Biology, Saint Peter's University, Jersey City, USA. ${ }^{2}$ Department of Geosciences, University of Arkansas, \\ Fayetteville, USA. ${ }^{3}$ Department of Biological Sciences, University of Arkansas, Fayetteville, USA. \\ *brandygarrettkluthe@gmail.com
}

\begin{abstract}
Folklore surrounding an abandoned cemetery located in Johnson County, Arkansas (a part of the Louisiana Purchase) suggested that it was used by early settlers. Historical records were combined with several dating techniques to determine the approximate time periods that Cedar Grove Cemetery was established and abandoned. Cores extracted from trees located adjacent to or on graves provided evidence that the cemetery was abandoned in the 1920s. These results coincide with the last burial event in 1922. The approximate age of undated gravesites was determined using lichenometry. A lichen growth rate of $0.0685 \mathrm{~cm} /$ year was determined for lichens present on two gravestones with known dates. This growth rate was then applied to the undated graves to establish their approximate ages. Death dates from historical records of individuals buried in the cemetery matched the dates established by the lichen growth rate. Our results show that many of the unmarked graves date prior to the first documented private ownership of the land. The results of this study support local folklore passed down over several generations about the origin of the cemetery.
\end{abstract}

Received March 23, 2018

OPENӘACCESS

Accepted August 8, 2018

DOI 10.14237/ebl.9.2.2018.1296

Keywords Lichenometry, Folklore, Dating, Cemetery, Tree-ring

Copyright (c) 2018 by the author(s) licensee Society of Ethnobiology. This is an open-access article distributed under the terms of the Creative Commons Attribution-NonCommercial 4.0 International Public License (https://creativecommons.org/licenses/by-nc/4.0), which permits non-commercial use, distribution, and reproduction in any medium, provided the original author and source are credited.

\section{Introduction}

Verifying folklore associated with historical sites or events is challenging when historical documents are not available (Dorson 1961). Scientific methods used to date objects and places are commonplace today; these tools allow us to verify information that previously existed only as historical tradition (Wagner 2007). In the absence of historical documents, dating techniques for early American sites commonly rely on artifacts-such as pottery-which are uncovered during excavations (Adams 2003). This study examined the possibility of using both dendrochronology and lichenometry as tools for dating early American sites when historical documents and artifacts are insufficient or unavailable for dating the age of a site.

The study site is located between the Boston Mountains and the Arkansas River Valley. An old cemetery known as Cedar Grove Cemetery, it is now mostly covered with vegetation, the graves sunken in, and many of the headstones toppled (Figure 1). Small trees currently grow throughout the area both near and over marked gravesites. According to local folklore, this cemetery was established by early white settlers who traveled through the mountains to begin a new life in the Louisiana Purchase, in what would become the state of Arkansas. Not every person survived this journey, so the cemetery was established and became their final resting place. Rough cut headstones hewn from local sandstone were used to mark the graves, although some of these no longer have any markings, if they ever did.

Historical documents provide little information as to who may have been buried in the unmarked graves. Dates on some of the gravestones indicate that the cemetery was already present when the land was deeded from the government to the first landowner, Jesse Mason, in 1883 (General Land Office 2012). There is some indication that the land was used prior to this date. The land survey of 1831 (General Land office 2012) showed square fields indicative of farming. A few miles south of the cemetery a small 

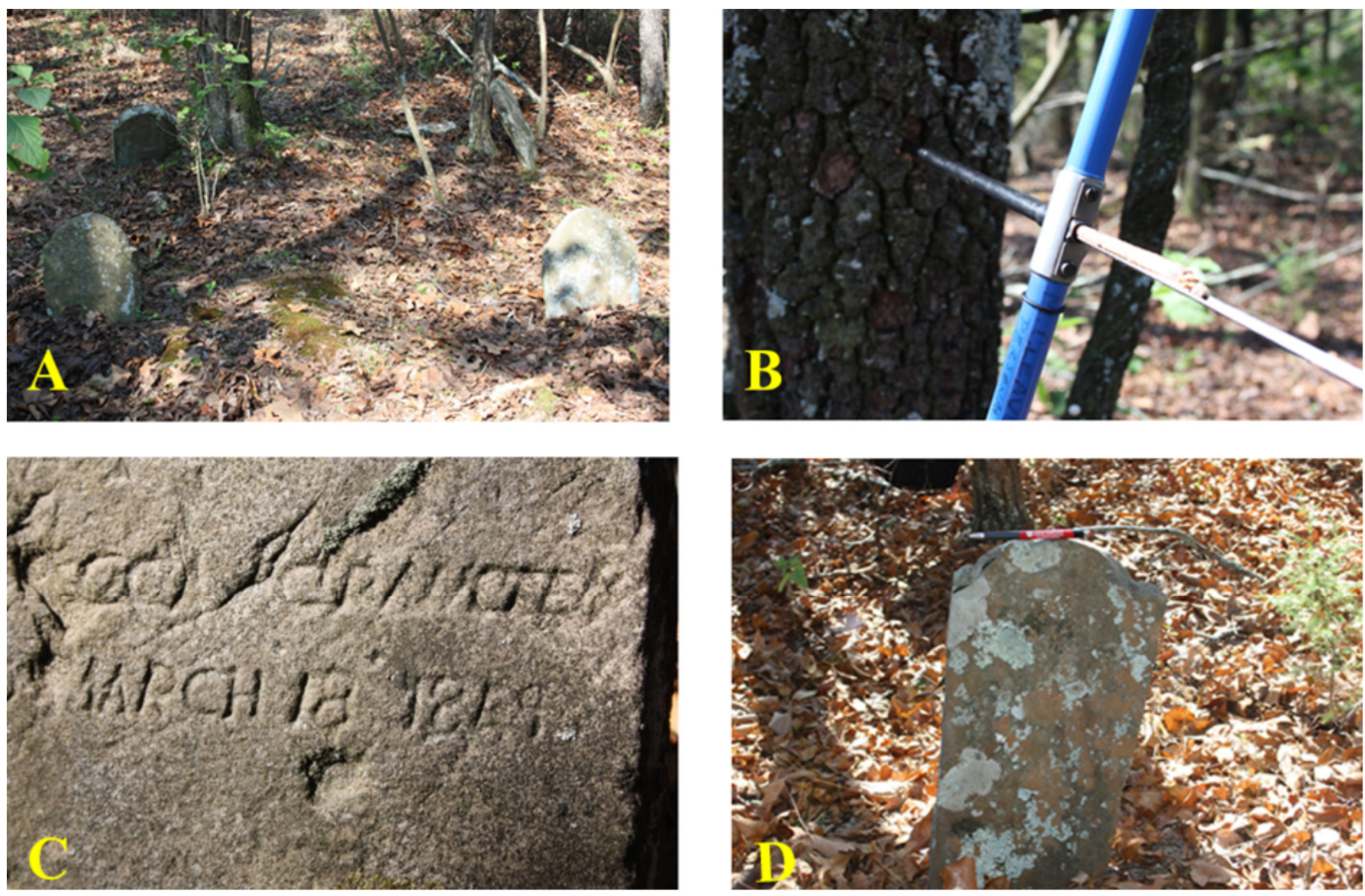

Figure 1 Cedar Grove Cemetery near Clarksville, AR. A) Site of cemetery with gravestones present. B) Increment borer used to sample trees on or near gravesites. C) One of the few gravestones (GS 12) with writing; the date is difficult to decipher but information from historical documents made it possible to verify the date as 1859 . D) This gravestone was covered with the two specimens of lichen identified. (Photographs taken by Brandy Garrett Kluthe).

creek flows towards the former site of a large trading post on the Arkansas River, in use several decades before the acquisition of the Louisiana Purchase (Key 2001).

Dendrochronology, lichenometry, and historical records were used to determine the age of the headstones. Dendrochronology has been successfully used to determine approximate dates for historical and archaeological structures; those techniques were applied to this study (Bannister and Robinson 1975; Pearson el al. 2013). Trees now present on or adjacent to headstones likely became established only after the graves were in place. Lichen growth rates were another means of dating the headstones. Lichens grow at a near constant rate, and they are useful in dating objects that are relatively undisturbed (Muller 2006). This is a common method of determining growth rate within a small area (McCarroll 1995).
Lichen growth rates can be determined by using headstones with dates on them to calculate growth rate based on a known date.

The aim of this study is to use modern dating techniques to determine the approximate age of the unknown graves in Cedar Grove Cemetery. Dendrochronology and lichenometry, combined with historical documents, will help to fill in the knowledge gaps surrounding the Cedar Grove Cemetery. By establishing dates for the unknown graves, we test the hypothesis that the cemetery was established before the land was first surveyed and settled. This would support the local folklore surrounding the establishment of the cemetery which indicates that it was used prior to the date of the Louisiana Purchase.

\section{Historical Background}

Arkansas was part of the Louisiana Purchase that the 
United States acquired from France in 1803. During the early to mid-1700s, prior to the transfer of the land to the United States, several early French colonists had produced fairly detailed maps of the area, including the area surrounding the cemetery site (Sayre 2010). One of the first trading posts in Arkansas was on Spadra Bluff, which is located in Johnson County, Arkansas, just a few miles south of the cemetery site. At the time of the Louisiana Purchase, French traders had been established in the general area for decades (Key 2000). This trading post was a place for fur traders, both white and American Indian, to purchase supplies and sell furs. Several trading houses were in the vicinity, and it is easy to imagine that settlers would radiate out from this post (Key 2000). Spadra Bluff derives its name from the stream that flows south into the Arkansas River adjacent to the post site. This stream passes very closely to the Cedar Grove Cemetery.

The U.S. government surveyed the land within the Louisiana Purchase in the decades following its acquisition. In 1831 surveyor William Clarkson produced the plat for Section 27 of the Clarksville Quadrangle, where the cemetery is located. The use of U.S. General Land Office (GLO) records can be helpful in determining land ownership, usage, and the types of vegetation characteristic of a particular landscape, although caution must be used. Not all of the surveyors working in an area were reliable, and the records they produced were not always accurate (King 1978). Although the plat does not suggest that Clarkson was not skilled, it also does not show the cemetery, although some of the gravesites were dated to be older than the time of the survey. Looking at the survey transect, the survey does not pass through the boundary of the cemetery. Clarkson would not necessarily have seen the cemetery in this large tract of land if he did not stray far from his transect.

There is some conflicting data as to who first homesteaded the property. As noted earlier, the first official recorded ownership of the land (General Land Office 2012) where the cemetery is located was to Jesse Mason in 1883. Regardless of ownership, there is considerable evidence to support the presence of white settlers, either French or American, in the area surrounding the cemetery site well before it was first homesteaded. This establishes the fact that people were around who would have died and been buried in the manner that was evident at the cemetery site. This information supports the scientific data collected from the gravestones, described below, which clearly show that the gravesites were established well before the first homesteaders were recorded.

\section{Methods}

The precise location of the cemetery, which is not recorded on United States Geological Survey (USGS) maps, was determined using a handheld GPS unit (Trimble Geo XT). This information was used to locate historical information in the GLO records available on the Bureau of Land Management website (General Land Office 2012). The GPS unit was also used to record the site of each gravestone, the location of lichens used for measurements and samples, and trees from which cores were extracted. These data were then used to create a map of the cemetery, pinpointing the exact location of the samples collected (Figure 2).

Cores were extracted from all living trees that were growing directly over or next to a grave site, regardless of species. In addition, two trees not located on or adjacent to a grave but which appeared to be within the bounds of the original cemetery were included to provide a more inclusive sampling of the trees present. The primary species collected were eastern red cedar (Juniperus virginiana L.) and white oak (Quercus alba L.), along with one red oak (Quercus rubra L.). All cores were taken in 2012.

Core samples were extracted with a standard increment borer. The cores were taken at breast height (height approximately $1.30 \mathrm{~m}$ from the ground) and stored in straws labeled with the collection number. The cores were allowed to dry and then mounted on wood blocks. Dried cores were sanded to achieve a smooth surface for viewing. The cores were analyzed with a stereomicroscope and rings were counted three times in the dendrochronology lab at the University of Arkansas. Each ring represents one year of growth. Extra care was taken when counting rings of eastern red cedar since this species sometimes produces false rings (Stahle and Wolfman 1985). Some of the eastern red cedars sampled had internal heart rot; for those samples approximate ages were recorded and absolute ages were obtained by crossreferencing ring data with red cedars growing nearby.

The lichen measurements were taken from specimens growing on 16 gravestones. All measurements were taken from east-facing gravestones to ensure a high level of growth consistency. No measurements were taken from 
EtThNobiology Letters Data, Methods \& Taxonomy

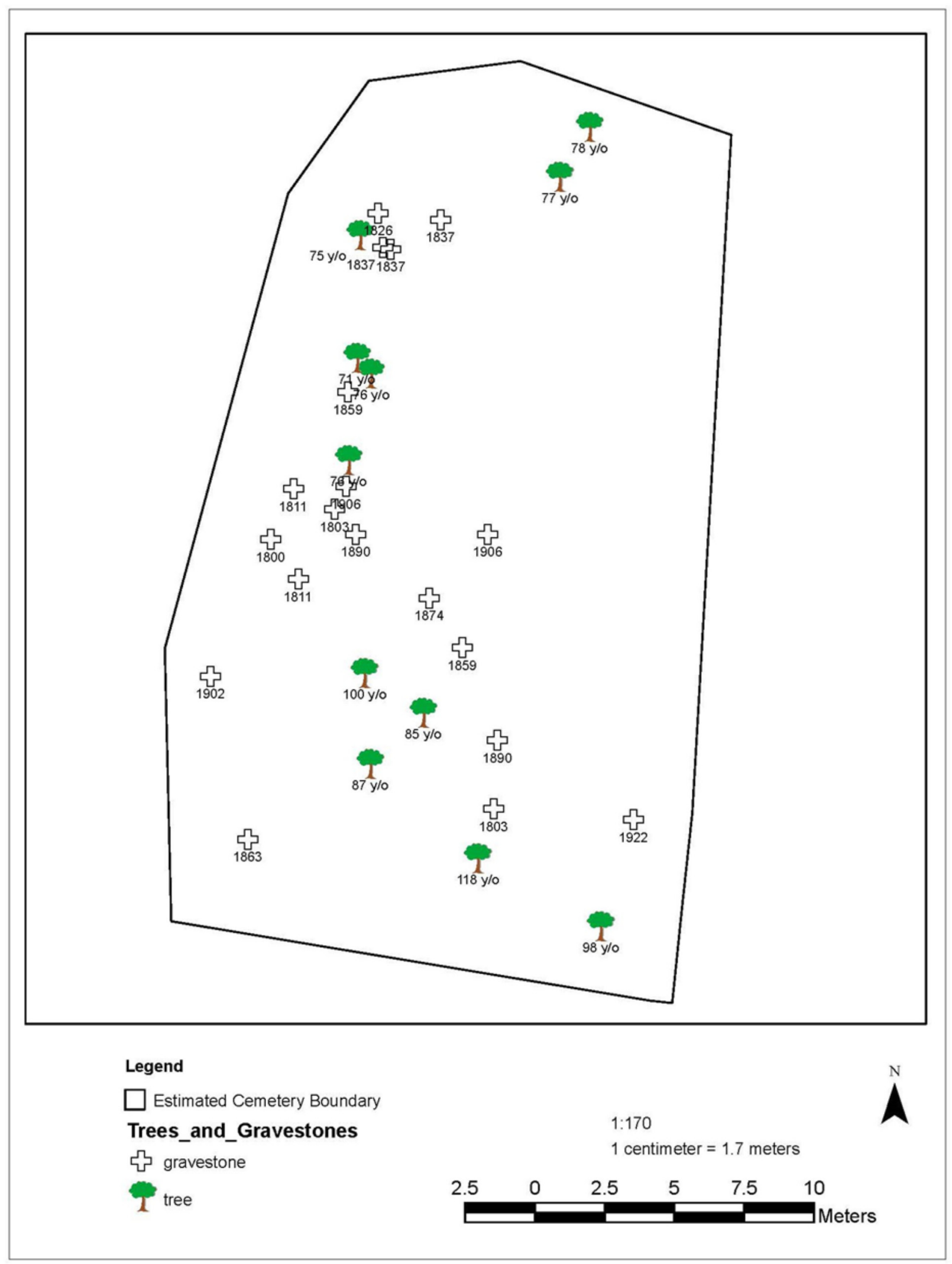

Figure 2 Map of sampled trees and gravesites with representative ages. 
gravestones that were toppled over. Only the largest and most complete lichens and those that did not overlap with adjacent specimens were measured. Two types of lichens were found to grow on the gravestones. Measurements were obtained from the dominant species, Parmotrema reticulatum. This species of lichen is common in the area and occurs predominantly on rocks. A ruler was used to measure these lichens in centimeters to the third decimal place. The ruler was placed at one edge of the lichen and extended across to the other edge, making sure that the line of measurement passed through the center point (Armstrong 1993). Initial measurements were documented twice to ensure accuracy. All field work was carried out during the months of September and October, 2012.

Historical records including GLO records, USGS maps, death records, and cemetery data were collected and analyzed for specific information regarding the site of Cedar Grove cemetery (General Land Office 2012; Johnson County Historical Society 2012). Records obtained from the county historical society had two records that verified the dates on some of the gravestones (Johnson County Historical Society 2012). Conversations with the landowner and neighbors provided folklore about the cemetery. These sources are expanded on in the discussion section below.

\section{Results}

The results obtained from the tree cores are presented in Table 1. Trees ranged in age from 71 years to 118 years. Visual inspection of the trees showed a wide range in diameter at breast height $(\mathrm{DBH})$ but the trees were very close in age (mean 75.5 years) with the exception of the trees in the southern section of the cemetery. These trees ranged in age from 85-118 years. As described above, two trees not directly over or adjacent to grave sites were included to allow for a more complete sampling of the cemetery trees: a white oak with an age of 98 years, in the southern portion of the area sampled, and an eastern red cedar aged 118 years old that could have been located outside of the cemetery since it was the second southernmost tree cored.

A comparison of tree ages and gravestone ages shows that the trees near every grave site are several years younger than the established age of the gravestone (Figure 2). The ages of trees located near or over grave sites indicate that the cemetery was abandoned around the time of the last marked grave.
Table 1 Species name and number of tree rings counted for all trees sampled in Cedar Grove Cemetery. Each tree ring represents one year of growth. This information was used to determine the approximate age of abandonment of the cemetery.

\begin{tabular}{lll}
\hline $\begin{array}{l}\text { Tree } \\
\text { sampled }\end{array}$ & Tree species & $\begin{array}{l}\text { Tree rings } \\
\text { counted }\end{array}$ \\
\hline 1 & Eastern Red Cedar & 78 \\
2 & Eastern Red Cedar & 77 \\
4 & Eastern Red Cedar & 75 \\
5 & Red Oak & 76 \\
6 & Eastern Red Cedar & 71 \\
7 & White Oak & 76 \\
8 & Eastern Red Cedar & 85 \\
9 & Eastern Red Cedar & 100 \\
10 & White Oak & 87 \\
11 & Eastern Red Cedar & 118 \\
12 & White Oak & 98 \\
\hline
\end{tabular}

While tree ages alone did not provide sufficient evidence to support the pre-Louisiana Purchase date of the cemetery accorded by folklore, these trees do indicate that the site was relatively undisturbed, making it ideal for applying lichenometry for dating the unmarked gravestones.

Lichens showed a wide range of diameters, indicating an apparent difference in ages (Table 2). The lichen diameters ranged from $3.81 \mathrm{~cm}$ to 12.19 $\mathrm{cm}$. A gravestone marked from 1922 included a lichen with a diameter of $3.81 \mathrm{~cm}$, while the 1859 gravestone had a lichen diameter of $8.12 \mathrm{~cm}$, visually indicating a difference in age. By subtracting the diameter of the 1922 lichen from the 1859 lichen, and diving by the number of calendar years separating the two gravestone dates, a lichen growth rate of $0.0685 \mathrm{~cm} /$ year was calculated for the years between 1859 and 1922.

A second growth rate was determined by taking the diameter of the lichen on the 1922 gravestone and dividing the value by the number of years from 1922 to 2012. This provided a different growth rate value of $0.0423 \mathrm{~cm} /$ year for the period 1922-2012. The latter growth rate was deemed to have been affected by changes following the abandonment of the cemetery, as described below, so the pre-1922 growth rate was used exclusively to estimate the age of gravestones of unknown date.

The ages of the gravestones was therefore calculated by subtracting the diameter of the 1922 gravestone lichen $(3.81 \mathrm{~cm})$ from each of the other 
Table 2 Ages of sampled gravestones using lichen growth rates and historical records. As outlined in the text, the calculated lichen growth rate from 1811 to 1859 is $0.0689 \mathrm{~cm} /$ year, with a $0.0685 \mathrm{~cm} /$ year lichen growth rate from 1859 to 1922 . The calculated age of the gravestones was determined using the $0.0685 \mathrm{~cm} / \mathrm{year}$ rate, as described in the text. The calculated age of the gravestones is verified by historical records and can be used to determine the age of gravestones previously unknown.

\begin{tabular}{|c|c|c|c|c|}
\hline \multicolumn{5}{|c|}{ Age of gravestone } \\
\hline Gravesite & Lichen diameter $(\mathrm{cm})$ & Calculated age & Historical records & Calculated date \\
\hline GS 1 & 3.81 & 71 & 1922 & 1922 \\
\hline GS 2 & 8.128 & 151 & & 1859 \\
\hline GS 3 & 7.112 & 132 & & 1874 \\
\hline \multicolumn{5}{|l|}{ GS 4} \\
\hline GS 5 & 7.874 & 146 & & 1863 \\
\hline GS 6 & 5.2 & 96 & & 1902 \\
\hline GS 7 & 11.43 & 212 & & 1811 \\
\hline GS 8 & 12.192 & 226 & & 1800 \\
\hline \multicolumn{5}{|l|}{ GS 9} \\
\hline GS 10 & 11.43 & 212 & & 1811 \\
\hline \multicolumn{5}{|l|}{ GS 11} \\
\hline GS 12 & 8.128 & 151 & 1859 & 1859 \\
\hline GS 13 & 9.652 & 179 & & 1837 \\
\hline \multicolumn{5}{|l|}{ GS 14} \\
\hline GS 15 & 10.414 & 193 & & 1826 \\
\hline GS 16 & 9.652 & 179 & & 1837 \\
\hline GS 17 & 9.652 & 179 & & 1837 \\
\hline \multicolumn{5}{|l|}{ GS 18} \\
\hline GS 19 & 4.9 & 91 & & 1906 \\
\hline \multicolumn{5}{|l|}{ GS 20} \\
\hline \multicolumn{5}{|l|}{ GS 21} \\
\hline GS 22 & 11.938 & 221 & & 1803 \\
\hline GS 23 & 6 & 111 & & 1890 \\
\hline
\end{tabular}

gravestone lichen samples, and the duration of time needed to grow the remaining diameter was estimated using the pre-1922 growth rate of $0.0685 \mathrm{~cm} /$ year. Thus, this calculation provides the number of years that had passed between the lichen began growing and 1922. To determine the date of the gravestone, this number is then subtracted from 1922.

Support for the $0.0685 \mathrm{~cm} /$ year lichen growth rate is given by Gravestone 10. This grave had a date, but it was unknown if it was the birth or death date. Using the rate of $0.0685 \mathrm{~cm} /$ year for lichen growth, the date came out at 1811, which would correspond with the death date. By establishing that this was the death date, another lichen growth rate could be determined. The growth rate between the 1811 gravestone and the 1859 gravestone (GS 12) was then calculated to be $0.0689 \mathrm{~cm} /$ year, which is not significantly different from 0.0685 , as verified by a chi-square analysis. This consistency in lichen growth rates supports the assumption that outside factors, including successional growth, were not affecting the rate of lichen growth within the sample area prior to 1922, permitting dates to be established for unmarked gravesites.

By applying the $0.0685 \mathrm{~cm} /$ year lichen growth rate, the age of unmarked gravestones can be estimated. The gravestones ranged in age from 90 years to 212 years (Figure 3). The youngest is the verified 1922 gravestone and the oldest gravestone was established in 1800 (Gravestone 8). As illustrated in Figure 3, the cemetery was used at a steady rate from 1800 to 1922 . There is a strong correlation between the dates that were determined using lichen measurements and the dates from the cemetery 


\section{Graph of Gravesites Ranked by Age}

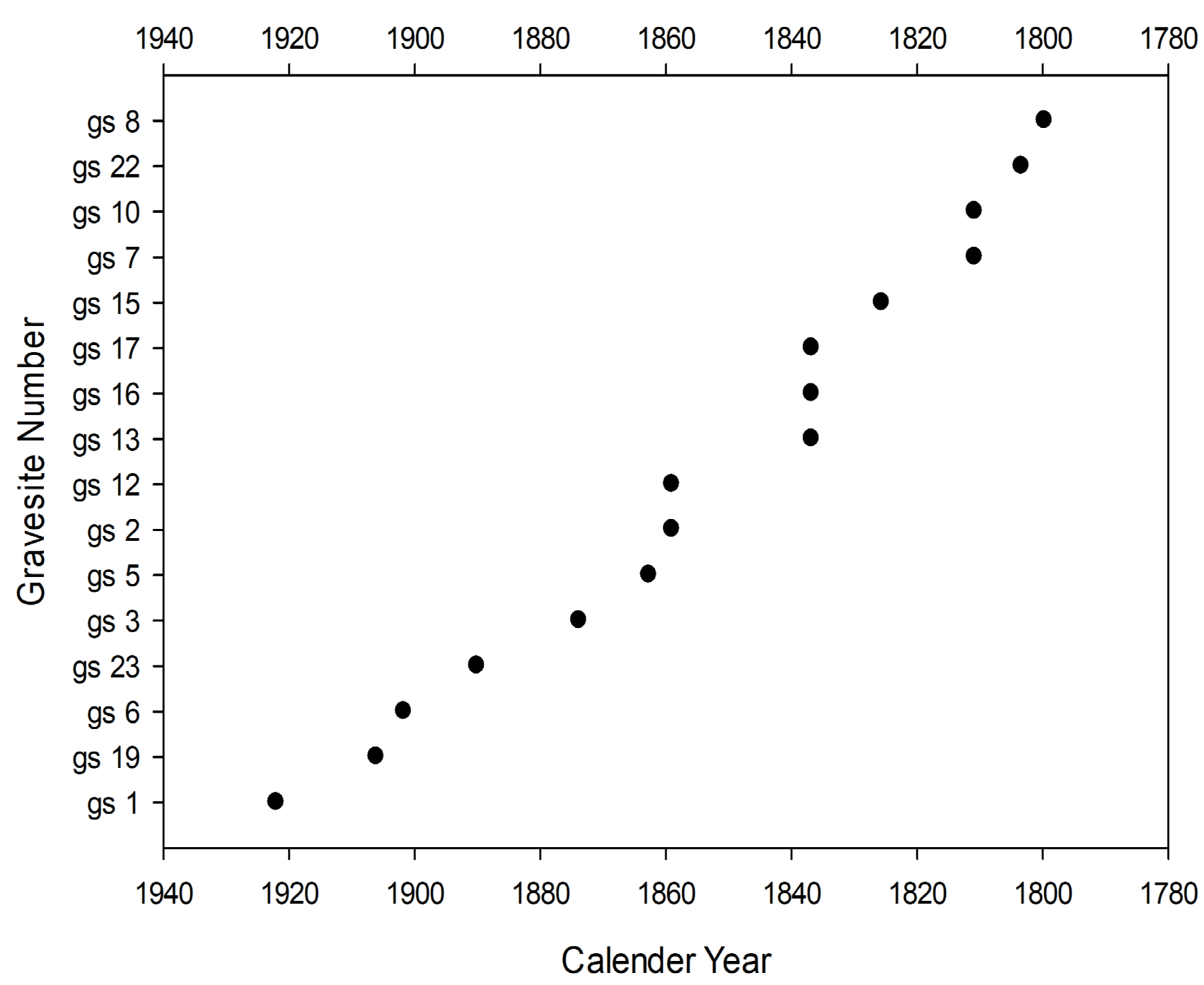

Figure 3 Ages of the sampled gravesites ordered by year of establishment. The graph shows a steady rate of use from the first grave to the last grave.

records. It is important to consider that not every gravesite had a gravestone, and that not all gravestones were measured for lichen growth. Taking this into consideration along with historical data, it is possible that the cemetery is actually older than 1800 .

\section{Discussion}

Dating Using Dendrochronology and Lichenometry

Dendrochronology and lichenometry data, combined with historical records, provide strong evidence that Cedar Grove Cemetery was established by white settlers prior to the acquisition of the Louisiana
Purchase and before the first survey maps were produced in the area (1831). The research techniques outlined in this study provide a novel approach to verifying verbal histories or folklore about sites when historical documents are not sufficient, do not exist, or have gaps. The results of this type of research approach can change our previously understood knowledge of a place. It can also provide a richer historical record by validating folklore. The combination of historical documents, local knowledge, tree age, and lichen growth rates was necessary to fully understand the history of Cedar 


\section{Grove Cemetery.}

The tree cores do not provide evidence that the cemetery was established prior to the acquisition of the Louisiana Purchase, but they do provide information about the time of last use and appear to indicate that the cemetery boundary might have shifted and was abandoned not at one time but over an extended period of time. Trees aged 85-118 years are found exclusively in the southern portion of the cemetery, suggesting that it may have been abandoned before the rest of the cemetery. This would make sense when considering the orientation of the cemetery to the entry point and the site of the most recent gravesite. Gravestone 1 is located in the southeast corner with the point of entry to the cemetery at the northern part of the sample area (Figure 2). Conversations with the current landowner and her neighbors indicate that the cemetery was actually surrounded by a fence when the last cemetery was established in 1922, and quickly deteriorated shortly after that time. The two oldest trees in the sample area may have been outside the boundary of this fence, although the fence is no longer present. The time frame of the cemetery abandonment established around 1922 is reasonable and does allow for early disturbance, possibly caused by seedling browse by cattle or deer, which deterred tree growth until approximately the early 1930s (Myster 2010). According to the current landowner, the property was used for grazing cattle until the late 1970s. On one visit to the site, deer were also observed within the area sampled.

Considering the age of the trees, it seems likely that the cemetery ceased to be maintained just a few years after the last grave was established. The lack of maintenance to the site allowed tree seedlings to became established within the boundary of the sample area, including those individuals growing over and adjacent to gravesites. This also allowed for a change in the understory vegetation. Privet (Ligustrum sp.), which may have been planted on the boundary of the cemetery, spread to cover the entire western edge of the graveyard at the time of study. Gravestone 1 was found in the dense vegetation along with Gravesite 21. Other graves may be present along the western portion, but the understory growth was so dense that it was impossible to visually examine or attempt to sample. Other vegetation within the sample area included a woody overgrown rhododendron (Rhododendron sp.) and a thorny vine of either a wild rose (Rosa sp.) or blackberry (Rubus sp.).

While successional growth within the sample area and the cemetery as a whole did not turn out to be critical to the questions being asked about the age of the gravestones, it does provide some answers to the changes in lichen growth rate after the last grave was established. The trees were not present when the greater portion of the cemetery was established. As the trees grew, they changed the amount of sunlight and moisture that would be received by the lichens growing on the gravestones. This change would account for the difference in the lichen growth rate per year after the 1922 gravesite had been established (Armstrong 1993). Evidence to support this interpretation came from historical records.

\section{Integrating Historical Records}

The lichens growing on the gravestones provided some insight into the age of individual unmarked gravestones. At the beginning of the study, an exact age for any single gravestone had not yet been determined. Two critical pieces of data provided the key for discovering the growth rate of the lichens. The first came from Gravestone 1. This gravestone had not been observed in the initial visit to the cemetery. The gravesite was located in a dense thicket of privet growing on the western boundary of the site. The gravestone markings were clearly visible and confirmed that it was put in place in 1922.

The second critical piece of information came from a visit to the Johnson County Historical Society. The historical society actually had a file for this cemetery, which has been called by many names, including the Cedar Grove Cemetery, Mason Cemetery, and Darnell Cemetery. In the 1950s a local homemakers' club decided to inventory all the cemeteries in the county. They visited the various cemeteries and wrote down the information found on the gravestones and then verified this information through the Arkansas Death Index and through interviews with residents who recalled ancestors buried in the cemeteries. In addition to the 1922 gravesite, only two other gravestones in this cemetery had markings. Gravestone 12 was one that was able to be verified by the information collected from the homemakers group. The date of March 18 could be read, but the year was too badly weathered. The group verified the year as 1859 . With two verified dates, the lichen growth rates were determined for this site.

Another lichen growth rate could be determined 
using the current year and the newest grave established in 1922, but this presented problems. It is assumed that from the establishment of the cemetery to when it was abandoned major changes in the site did not occur, and that the rate of lichen growth would have been relatively constant. When the lichen growth rate from 1922 to present was calculated, the rate was different from the 1859 to 1922 growth rate. One explanation for this change in growth rates could be linked to the change in vegetation.

It is possible to obtain an estimate for how the landscape has changed using GLO records. These records did not have any information about the specific vegetation in the area, but it is thought that the climate was wetter and colder than today, which would affect the rate of growth (Bragg 2004). Another major consideration is the growth of the trees up and around the gravesites. Lichen growth rate is determined by the amount of sunlight and rainfall (Armstrong 1993). Both of the factors would have been changed with the establishment of trees in the cemetery and sample area. Although lichen growth rates were not statistically different for the period of 1811-1859 and 1859-1922, using different growth rates would slightly change some of the dates of the graves. For this reason, the growth rate established between 1859-1922 was used to determine the age of all sampled gravestones, which established the date of the oldest gravestone to be 1800 .

The data collected was used to support the folklore about the use and origin of the cemetery. The methods outlined provide a means for dating other sites when historical documents are limited or not available.

\section{Conclusions}

Stories passed down through generations become folklore relating to people, places, and events. The stories passed down about Cedar Grove Cemetery indicate that it was used by the earliest settlers in Johnson County, Arkansas. In the present study, historical evidence and modern scientific dating techniques were employed to validate this local folklore. Measurements of lichens growing on the gravestones established a rate for their growth which, along with verifiable gravesite dates, was able to establish the age of many of the gravestones within the cemetery. Tree ring data indicate that the majority of the trees were established after the last gravesites were dug. Land patent records indicate that the land was first deeded to Jesse Mason in 1883. The GLO records along with other historical records indicate that people were using the area before it was deeded to Jesse Mason. The date of the oldest dateable grave was determined to be 1800 , with a steady rate of use until the most recent gravesite was established in 1922. This evidence strongly supports the folklore that the cemetery was established and used well before the land was formally homesteaded. It may never be known who is buried in this cemetery, but modern science has been able to determine, in the case of the Cedar Grove Cemetery, that sometimes there is truth to stories that are passed down through generations.

\section{Declarations}

Permissions: None declared

Sources of funding: None declared.

Conflicts of Interest: None declared.

\section{References Cited}

Adams, W. H. 2003. Dating Historical Sites: The Importance of Understanding Time Lag in the Acquisition, Curation, Use, and Disposal of Artifacts. Historical Archeology 37:38-64. DOI:10.1007/BF03376602.

Armstrong, R. A. 1993. Factors Determining Lobe Growth in Foliose Lichen Thalli. New Phytologist 124:675-679. DOI:10.1111/j.14698137.1993.tb03857.x.

Bannister, B. and W. J. Robinson. 1975. Tree-Ring Dating in Archaeology. World Archaeology 7:210-225. DOI:10.1080/00438243.1975.9979634.

Bragg, D. 2004. General Land Office Surveys as a Source for Arkansas History: The Example of Ashley County. The Arkansas Historical Quarterly 63:166-184. DOI:10.2307/40024079.

Dorson, R. 1961. Ethnohistory and Ethnic Folklore. Ethnobistory 8:12-30. DOI:10.2307/480346.

General Land Office. 2012. Records Housed within the Bureau of Land Management [web page]. Available at: http://www.glorecords.blm.gov/ details/survey/default.aspx? $\mathrm{dm} \_\mathrm{id}=4016 \&$ sid $=\mathrm{kr} 4 \mathrm{ygmjn} .134$. Accessed on November 15, 2012.

Johnson County Historical Society. Cedar Grove Cemetery Physical Records Housed in the Johnson County Historical Society Archives, Clarksville, AR. Accessed on October, 2012. 
Key, J. P. 2000. Indians and Ecological Conflict in Territorial Arkansas. The Arkansas Historical Quarterly 59:127-146.

King, F. B. 1978. Additional Cautions on the Use of the GLO Survey Records in Vegetational Reconstructions in the Midwest. American Antiquity 43:99-103. DOI:10.2307/279638.

McCarroll, D. 1995. Lichens: Lichenometric Dating of Diachronous Surfaces. Earth Surface Processes and Landforms 20:829-831. DOI:10.1002/ esp.3290200908.

Muller, G. 2006. Lichenometry and Environmental History. Environmental History 11:604-609.

Myster, R. W. 2010. A Comparison of Tree Replacement Models in Old Fields at Hutcheson Memorial Forest. Journal of the Torrey Botanical Society 137. DOI:10.3159/09-RA-012.1.

Pearson, C. L., C. B. Griggs, P. I. Kuniholm, P. W. Brewer, T. Wazny, and L. Canady. 2012. Dendroarchaeology of the Mid-First Millennium $\mathrm{AD}$ in Constantinople. Journal of Archaeological Science 39:3402-3414. DOI:10.1016/j.jas.2012.05.024.
Sayre, G. M. 2010. A Newly Discovered Manuscript Map by Antoine-Simon le Page du Pratz. French Colonial History 11:23-45.

Stahle, D. W., M. K. Cleaveland, H. D. GrissinoMayer, R. D. Griffin, F. K. Fye, M. D. Therrell, D. J. Burnette, D. M. Meko, and J. Villanueva Diaz. 2009. Cool- and Warm-Season Precipitation Reconstructions over Western New Mexico. Journal of Climate 22:3729-3750. DOI:10.1175/2008JCLI2752.1.

Stahle, D. W., and D. Wolfman. 1985. The Potential for Archaeological Tree-Ring Dating in Eastern North America. Advances in Archaeological Method and Theory 8:279-302. DOI:10.1016/B978-0-12-0031085.50012-9.

Wagner, G. A. 2007. Chronometric Methods in Paleoanthropology. In Handbook of Paleoanthropology, edited by W. Henke, T. Hardt, and I. Tattersall, pp. 311-338. Springer Verlag, Berlin, Germany. 